more somber assessment views the present and immediate past.

What concerned Whitman in the postbellum years was a fundamental problem in U.S. culture: how can we foster a deep sense of community within an individualistic democracy, how nurture moral and affective ties between citizens and the state?

\title{
NOTES
}

1 Reproduced with permission from Walt Whitman Collection (\#3829-Y), Clifton Waller Barrett Library, The Albert H. Small Special Collections Library, University of Virginia Library.

2 Whitman, Two Rivulets (Author's Edition: Camden, NJ, 1876), 23. This passage can also be found in Prose Works 1892, ed. Floyd Stovall (New York: New York University Press, 1964), 2:512.

\section{REDISCOVERED NINETEENTH-CENTURY WHITMAN ARTICLES}

The following items reprinted from late nineteenth-century newspapers fill a couple of niches in Whitman scholarship. In the first, the Washington correspondent of the Springfield Republican comments on Whitman's admiration for Emanuel Leutze's mural "Westward the Course of Empire Takes Its Way," which has hung in the rotunda of the U. S. Capitol since 1861. The second item establishes the exact date and text of Richard Maurice Bucke's report of Whitman's lecture on Lincoln in Philadelphia in April 1880. The third item is a substantial 1886 interview with Whitman. Finally, I append a note on an early printing of excerpts from the 1893 In Re Walt Whitman.

1. E. K., "Surface Life at Washington," Springfield Republican, February 16, 1869, 2:5; excerpted in New York Evening Post, February 17, 1869, 1:2.

Walt Whitman wanders up and down the avenue daily_and he and Beau Hickman seem the only blots on the landscape. Whitman never carried his eccentricities of appearance to greater lengths than now. I met him yesterday, standing in front of Leutze's picture, 'Westward the Star of Empire takes its way,' and leaning royally against one of the pillars, talking down to a group of effete little women who were perhaps deifying him. His hair, which the old poet gives free scope, falls below his shoulders, and his head is crowned by an immense, weather-stained hat, broad-brimmed as a Quaker's, and 'skewed' all out of shape. His overcoat is rowdy, his gloves are unbuttoned; his aspect is as distract as a lover's. What a splendid waste of raw material! How much more the poet and the man he would look in a decent coat and a pair of cotton gloves! He said he had been ill, but was now engaged in writing something describing 'the merging of all things in nature into each other'-something like Carlyle's chapter called 'Epimenides'1 — perhaps. The ladies looked wondrously amazed, and Walt, taking up a little child near by, held it up to explain to it Leutze's masterpiecekissing it tenderly as a woman between his long, ambling, loose-jointed, descriptive sentences. 
The painter Emanuel Gottlieb Leutze (1816-1868) gleaned the title of his mural from a line of verse by the eighteenth-century Irish poet George Berkeley, subsequently cited by John Quincy Adams in his "Oration at Plymouth" (1802). The painting, which depicts a band of pioneers crossing a rustic landscape, may have helped to inspire Whitman to celebrate Manifest Destiny in such verses as "Passage to India" (1871), especially lines like "I hear the echoes reverberate through the grandest scenery in the world, / I cross the Laramie plains, I note the rocks in grotesque shapes, the buttes. . .."

\section{2. [Richard Maurice Bucke,] "The Martyr President / The Good Gray Poet's} Personal Recollections of Him," Philadelphia Press, April 16, 1880, 5:1-3.

A lengthy transcription of Whitman's lecture on Abraham Lincoln in Association Hall in Philadelphia the day before. "His method of delivery was wholly devoid of tricks of elocution, the sentences being uttered in a tone only sufficiently higher than he would make use of in talking to a friend to make sure that the most distant hearer would catch every word. Occasionally, in speaking of his personal affection for emancipation's martyr, his voice trembled and the eyes of not a few of his hearers were tearful."

This transcription of Whitman's lecture is a slightly abridged version of the text reprinted in Prose Works 1892, ed. Floyd Stovall (New York: New York University Press, 1964), 2:497-509. It is cited in Daybooks and Notebooks, ed. William White (New York: New York University Press, 1978), 1:183; and it is listed as item 1880.B13 in Scott Giantvalley's Walt Whitman, 1838-1939: A Reference Guide (Boston: Hall, 1981), but it is incorrectly dated in both volumes. Though this article has been known to exist, then, its exact date of publication and contents have been unknown until now.

3. W[illiam] H[osea] B[allou], "Talks With Noted Men / Walt Whitman in His Modest Home in Camden," Chicago Tribune, June 12, 1886, 10:3-4.

The following interview with Whitman in June 1886 has hitherto been lost to scholarship. It was conducted by the natural scientist and local journalist William H. Ballou (1857-1937), who had published another interview with the poet only the year before. ${ }^{2}$

Walt Whitman has not written a line of poetry for over a year. "I am waiting for the muse," he said sadly when I spent the day with him recently. He lives in precisely the last spot on earth that a poet would naturally select. Philadelphia has an imitation of Brooklyn in the form of Camden, N.J., which is as dusty and unpleasant a place as one can imagine. The Delaware River, which must be crossed to get there, is invariably covered with oil which diffuses its fumes through the riparian air. After a ride across this stream one follows a railway up to Fourth street, turns to the right one block to Mickle street, where Whitman's little house stands, shaken by heavily-laden trains, changing car-bells, and shrieking whistles. Around the house are smoking, noisy manufactories. On one side is a police and fire station and on the other a small grocery and a saloon. A single tree shades the little wooden structure in front, on which a flock of sparrows have established a claim and set the gray bard's poems to music.

"How kind of you to come," he always says, "and what is the news from the world? Is there any progress in science, religion, or art?" These questions must be discussed 
at length before he will talk about himself. He sits by the window opening into the street nearly all day. Over his lower parts a huge skin of an unfortunate polar bear is always present, which is strangely in keeping with his long-flowing, silky white hair and beard. His voice is clear and musical, his senses perfect, and even at the age of 67 his mind shows no approach of dotage.

"I wish you would say to the public," he remarked, "how thankful I am for the recent manifestation of esteem. My publisher has only sent me $\$ 80$ as profits on my books for over a year. The profits on 'Leaves of Grass' were only $\$ 26$ for the same time. But my friends everywhere are remembering me. A young man in England recently sent me a $£ 50$ note, with a letter stating that he had come into his inheritance and wanted to divide with me. ${ }^{3}$ You know by the papers what other English friends have done. ${ }^{4}$ It would not be the truth to say that my only friends are in England. When I read my poem on Lincoln in Philadelphia the other day, the profits were $\$ 700 .^{5}$ Surely no one could be happier than I. The horse and carriage which was generously provided for me gives me daily recreation and pleasure. Suppose the muse never comes again and there remains but to sit, paralytic as I am, and live on sweet memories of the past and the final recognition of the present, is not my life a happy one? My spirits are buoyant and my health fair; I am indeed content."

"Do you intend to remain here the rest of your life?"

"Hardly; I have hopes of visiting New York in warm weather. I have friends there and boyhood associations to live over."

I cannot but recall Whitman's remarkable statements about the West. He regards the literary work of the East but the basis - the stimulus or nursery, as he calls it - of the great works that are to find their local origin in the West. He thinks that the prairies offer the grandest suggestions for the imagination. "I have spent," he said, "much of my life on the prairies and among the Rocky Mountains, and some of the poems I wrote there if left out of my works would be like omission of an eye from the human face. I am compelled to admit that my Western experiences are behind all my life work. There is a great poetic expression to come out of the soil conforming to the public and private life of the West. The primary materials of poetry are the same forever. It will never do to chew forever the poetry of the Old World, of which Shakespeare's is the most illustrious model. Poetry is a font of type, to be set up again consistently with American democratic institutions."

A day with Whitman is like passing one's time with some lofty being far above the present type of man, in another world, full of sunshine and songs of birds within, but all back and despairing without. There is not a pessimistic drop of blood in his veins. "I am no materialist," he declared. "I endeavor to combine the materialistic with the spiritualistic in all of my thoughts, written and unwritten, spoken and unspoken. I believe in the doctrine of Darwin-in evolution from A to Z. ${ }^{6}$ What you have told me of the advances of the theory by $\mathrm{Cope}^{7}$ and the other great evolutionists of the age is food to my soul. I can only be satisfied with a combination of a loftier and deeper theology and science than has ever been furnished. Everything is progressing toward that end as it should. The movements of our time in politics, science, religion, and sociology are toward a loftier conception of the human thought and constant upward tendency. I am content with the grand, sweeping advance, stamping an optimism on the age."

4. "Walt Whitman / New and Strong Lights on His Life, His Character and His Work," Philadelphia Inquirer, September 3, 1893, 9:1-7.

Excerpts several thousand words from proof sheets of In Re Walt Whitman, "obtained exclusively for this paper." Includes sections on "Whitman's Life," 
"The Whitman Family," "Letters to His Mother," "His Views on Immortality," etc. Also includes the first publication of Hamlin Garland's sonnet "Walt Whitman."

University of New Mexico

GARY SCHARNHORST

\section{NOTES}

1 The title of a chapter in Thomas Carlyle's History of the French Revolution (1837).

2 Scott Giantvalley, Walt Whitman, 1838-1939: A Reference Guide (Boston: Hall, 1981), item 1885.18.

3 Edward Carpenter (1844-1929). See Whitman, The Correspondence, ed. Edwin Haviland Miller (New York: New York University Press, 1969), 3:400.

4 Whitman had received about $£ 30$ from William Michael Rossetti two weeks earlier, the fifth installment in a total of about $£ 155$ he had received from British friends since September 1885 (Correspondence, 4:30).

5 Whitman read his "Death of Lincoln" lecture on April 15, 1886, at the Chestnut Street Opera House in Philadelphia. The benefit raised between $\$ 695$ and $\$ 700$ (Correspondence, 4:24 n.34).

6 Whitman's opinion of Darwinism is a much-disputed topic among Whitman scholars. See, for example, Gay Wilson Allen, The New Walt Whitman Handbook (New York: New York University Press, 1975), 24; and James T. F. Tanner's entry on Darwin in Walt Whitman: An Encyclopedia, ed. J. R. LeMaster and Donald D. Kummings (New York: Garland, 1998), 163.

7 Edward Drinker Cope (1840-1897), a paleontologist, editor of American Naturalist, a member of the National Academy of Sciences and the American Association for the Advancement of Science, and a native Philadelphian. Whitman would meet Cope in December 1889 (Correspondence, 4:403). 